Jurnal Pendidikan Dasar, 9 (1), Juni 2021

\title{
TEACHERS COMPETENCIES PROFILE IN DIGITAL LEARNING ERA: PROFESSIONAL ENGAGEMENT AND SELECTING DIGITAL RESOURCES
}

\author{
Budi Wibawanta ${ }^{1}$, Imanuel Adhitya Wulanata Chrismastianto ${ }^{2}$, Billy Mumu ${ }^{3}$ \\ ${ }^{1,2,3}$ Faculty of Education, Pelita Harapan University, \\ Jl. M. H. Thamrin Boulevard 1100 Lippo Village Tangerang, Indonesia 15811 \\ budi.wibawanta@uph.edu,imanuel.wulanata@uph.edu,billy.mumu@uph.edu
}

\begin{abstract}
Observing technological developments in the digital learning era with increasingly massive 21 st-century skills approach in the education sector must be responded to with professional teacher competence. This study aims to analyze the extent to which the teacher's competencies in professional engagement and selecting digital sources in the teaching and learning process. The research methodology used was survey research to subject's teachers as many as 61 respondents located at Dian Harapan Karawaci School, Tangerang. Respondent data collection was carried out by filling in an online questionnaire using google form media which was analyzed qualitatively descriptively. The results showed that the three aspects of a teacher's competencies profile in the digital learning era have been achieved in a good category so that they can meet the criteria for teacher's competencies profile as expected. Even though it has reached the good category, there are two sub-aspects with supporting items that need further efforts to improve teacher competence through professional development or similar teacher training, namely DCPD-3 and DCPD-4.
\end{abstract}

Keywords: Teacher, competencies, professional engagement, digital resources

\begin{abstract}
Abstrak: Mencermati perkembangan teknologi di era pembelajaran digital dengan pendekatan keterampilan abad 21 yang semakin masif di bidang pendidikan harus direspon dengan kompetensi guru yang profesional. Penelitian ini bertujuan untuk menganalisis sejauh mana kompetensi guru dalam keterlibatan profesional dan pemilihan sumber digital dalam proses belajar mengajar. Metodologi penelitian yang digunakan adalah penelitian survei kepada guru mata pelajaran sebanyak 61 responden yang berlokasi di Sekolah Dian Harapan Karawaci Tangerang. Pengumpulan data responden dilakukan dengan mengisi kuesioner online menggunakan media google form yang dianalisis secara deskriptif kualitatif. Hasil penelitian menunjukkan bahwa ketiga aspek profil kompetensi guru di era pembelajaran digital telah tercapai dalam kategori baik sehingga dapat memenuhi kriteria profil kompetensi guru seperti yang diharapkan. Meskipun sudah mencapai kategori baik, namun ada dua sub aspek dengan item pendukung yang perlu upaya lebih lanjut untuk meningkatkan kompetensi guru melalui pengembangan profesional atau pelatihan guru sejenis, yaitu DCPD-3 dan DCPD-4.
\end{abstract}

Kata Kunci : Kompetensi Guru, Profesionelaisme, Sumberdaya Digital.

Sumber: ICEHoS - International Conference onEducation, Humanities, and Social Science

103|J P D, p - I S S N : 2252 - 8156 , e - I S S N : 2579 - 3993 
long with the development of
technology in the current digital era, the increasingly massive 21 st century skills approach in the education sector must be responded to with professional competence of teachers in the teaching and learning process. The development of technology in learning can be seen from the existence of heutagogy learning designs and the explosion of information or knowledge due to the increasing use of the internet (Vickel Narayan, Jan Herrington, Thom Cochrane, 2019), lifelong learning (Ally, 2019), and artificial intelligence(Schmidt, 2017) greatly affects the existence of new demands on the roles and responsibilities of teachers in learning activities. The core abilities of the twenty-first century, such as literacy, problem solving, communication, and leadership are very much needed in today's world. These skills have become the focus of educational institutions around the world today, such as language skills and critical thinking, while several other skills that have recently emerged, namely digital skills. Twenty-first century skills comprise three main domains of knowledge: (1) innovative thinking; (2) information, media and ICT (information, communication and technology) skills (collectively referred to as "digital literacy", and (3) life and career skills.

The Sustainable Development Goals (SDGs) in the field of education explain that education must provide quality education for all. Online learning is one solution to be able to achieve equal education. Teachers play an important role in learning in facilitating student learning and being a bridge between students and community needs. The SDGs call for accessible education for all, but this may be difficult to achieve if teachers do not realize how to achieve this through their work using required skills. The future of such education will require teachers to have the skills to use digital technology to provide online teaching to students. With technology, students are the center of learning, where they develop their knowledge base and create an understanding of the world by being active learners.

The digital era will require "digital" teachers who must adapt to future education. Technology will play an important role in learning and 
in providing support to students. However, the massive use of other technology can interfere with learning objectives and must be in an appropriate portion, so that the use of technology in the classroom does not interfere with the natural and direct interaction between teachers and students. Almost all students are sensitive to the phenomenon of "new things" around the world. That means they are more critical and broadminded compared to students of the 20th century. Such circumstances require open-minded teachers to facilitate students who think more critically. With the help of technology (internet, smartphones, and social media), teachers are expected to have activities and assignments that are more relevant, current, and communicative in improving learning achievement in class and personal interactions.

Today's education is much different from a few decades ago because of the presence of technology that we must accept and take advantage of. The need for 21 st century teaching staff who are not only able to package all the things needed in the teaching and learning process with the power of the internet and high-tech gadgets and applications, but also must respect the characteristics of today's students. The shift towards 21-st century skills in the national education system is occurring and requires improvements in teacher skills and strategies in classroom learning.

Based on the background described above, the problem formulation in this study is what is the profile of teacher competence in the current era of digital learning in two aspects of the study? Thus, the purpose of this study is to identify and analyze the competency profile of teachers in the era of digital learning.

\section{LITERATURE REVIEW}

\section{Digital Competence and Digital Literacy}

Traditional approaches to developing digital skills in education have now been focused on promoting students' 'digital literacy'. Since the emergence of new technologies and new applications for technology, many of which have been generated by expanding internet access, and the spread of personal digital devices 
(smartphones), digital literacy has increasingly become the focus of developing educational goals (Karmijn van de Oudeweetering, Joke Voogt, 2018). Teachers must have technical skills in using digital tools and systems that are deemed appropriate to the educational setting, and identify how these can be used in specific learning units. However, this approach has been criticized for its narrow skills focus, failure to take into account different socio- cultural contexts for technology use, and its ineffective and reductive design (Anna Gruszczynska, Guy Merchant and Richard Pountney, 2013). Other research identifies limits in their overly technical approach that ignores broader considerations, including ethics, digital citizenship, health, welfare, safety, and social or collaborative elements(Teresa S. Foulger, Kevin J. Graziano, Denise A. Schmidt-Crawford, 2017). More recent studies or research suggest emphasizing digital literacy. Focusing on current skills has been abandoned, in favor of a broader digital competency model that recognizes the more diverse knowledge, abilities, and dispositions that future teachers require. Digital competence clearly involves more than just knowing how to use devices and applications that are closely related to skills to communicate with ICTs, as well as information skills. Use of ICTs requires specific knowledge and attitudes regarding legal and ethical aspects, privacy and security and understanding the role of ICTs in society and a balanced attitude towards technology(José Janssen, et al, 2013).

\section{Teacher's Competencies in Digital Learning Era}

The concept of digital competence in this study can be broadly defined as "the skills, knowledge, creativity, and attitudes needed by everyone to use digital media to learn and function in society. In this case, digital competence is understood as more than just the ability to use software or operate a device. Digital, but also includes various kinds of cognitive, motoric, sociological, and emotional skills that users must have to use the digital environment more effectively (Krumsvik, 2014). Experts mention the various forces that shape the future of education in the digital era. Prospective teachers as well as a 
teacher will have an impact on skills that provide education and support for quality learning. There are 9 competency areas in the digital era that must be possessed by a teacher, namely general competence, using technology, carrying out use digital learning resources or materials, combining digital learning resources, communicating with students, facilitating classroom learning, strategies in pedagogy, assessment in learning, and understanding students' personal characteristics.

\section{METHODOLOGY}

\section{Research Methods and Subjects}

This study was designed as a survey research to investigate research topics and collect related data required as the main source of information. The collected data were then analyzed using several categories constructed for research purposes to describe the topic. Therefore, the results of the data analysis will not involve statistical calculations, but rather the percentage of responses and the number of respondents. The subjects of this study were the teachers who taught at Dian Harapan School, Tangerang with a total of 80 respondents.
Sampling is done by random probability technique where all members in the population have the same probability or opportunity to be selected to be the sample. To avoid researchers' bias towards the subject, questionnaire respondents were allowed not to write their names. The research questionnaire would include two things, namely the competencies of twenty- first century teachers (10 dimensions) and 12 general competencies for future digital teachers. The questionnaire questions will be reviewed and validated by experts in the field of twenty-first century competence and piloted among primary and secondary school teachers.

\section{Data Analysis Technique}

The form of the questionnaire used is a structured questionnaire, in which questions are arranged in the form of rating scales or value scales. The value scale to be used is the Likert scale because it is very suitable to obtain information about the opinions and feelings of respondents in assessing a choice of answers to the questionnaire given using a fivepoint Likert scale and ranges from 1 (never), 2 (almost never) to 3 
(sometimes -Sometimes), 4 (almost always), and points 5 (always). The data collected through a questionnaire will be analyzed in a qualitative description. Qualitative descriptive analysis is carried out by providing a review or interpretation of the data obtained so that it becomes clearer and more meaningful.

The data collected using the questionnaire research instrument will be processed using the calculation of the average score for each question or statement divided by the number of respondents who answered the questions or statements in the questionnaire. The results obtained will be described by the average score obtained for each statement or question. After the questionnaire data is processed using the formula above, the next step is to categorize the results of each statement's score. The categories of scores obtained are as follows (Widoyoko, 2013):

Table 1 Likert Scale Interpretation

\begin{tabular}{cc}
\hline Scores & Category \\
\hline $4.5-5$ & very good \\
\hline $3.5-4.4$ & Good \\
\hline $2.5-3.4$ & enough \\
\hline $1.5-2.4$ & Less \\
\hline $0-1.4$ & very poor \\
\hline
\end{tabular}

\section{DISCUSSION}

\section{Professional Engagement}

After distributing questionnaires online to respondents who have been selected as samples in this study, the next process is to tabulate data and coding, and then analyze research data using a Likert scale. Professional engagement or the involvement of teachers professionally using digital technology in the learning process which can be analyzed through three supporting sub-aspects, namely the involvement of teachers professionally in using digital technology to improve communication with students and parents in developing and improving organizational communication strategies collaboratively (organizational communication), using digital technology to engage in collaboration with other educators, share and exchange knowledge and experiences, and collaboratively innovate in pedagogical practice (professional collaboration), and use digital technology for continuous professional development (digital continuous professional development).

Observing the results of tabulated data that have been 
calculated using the Likert scale and presented in table and figure 4.1 relating to the sub-aspects of Organizational Communication (OC), it shows that in item OC-1, namely the competence of teachers in using digital technology to communicate with students in the learning process categorized as very good with the achievement of results of 4.7. In item OC-2, namely the competence of teachers to use digital technology to communicate with parents as parties who support learning activities that are categorized as very good with 4.5 results. In the OC-3 item, namely the competence of teachers in using different digital communication tools and media (zoom, teams, google meet, etc.) according to the objectives and context of communicating, they are categorized as good with the achievement of results of 4.4. In item OC-4, namely the competence of teachers in discussing collaboratively about digital technology that can be used effectively for communication with peers (teachers and staff) in schools is categorized as very good with 4.5 results. Referring to the data analysis of the four items above, based on the category of achievement of results shown through the Likert scale interpretation, the teacher competency profile in the digital learning era and 21st century skills in the sub-aspects of Organizational Communication (OC) have been accumulatively achieved in a very good category (with 4.5) or have been able to meet the criteria for the teacher competency profile as expected. The results of diagrams from the sub-aspects of Organizational Communication (OC) can be shown as follows:

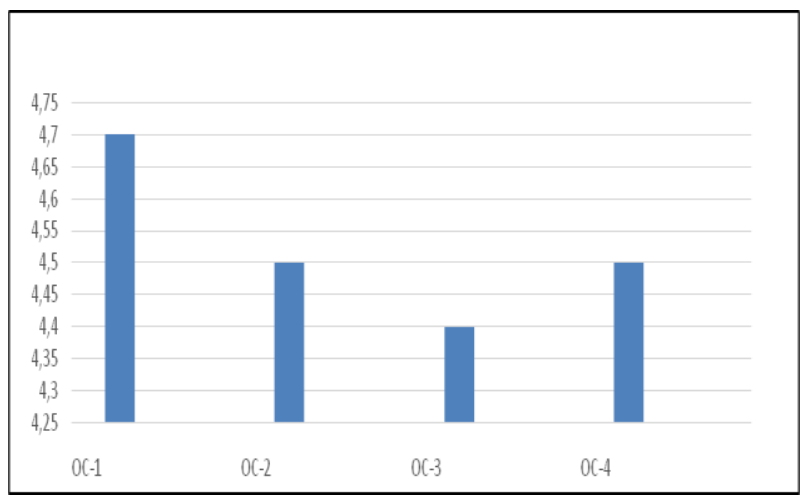

Figure 4.1

Data Tabulation Diagram Sub Aspects of Organizational ommunication (OC)

The next analysis of the subaspects of Professional Collaboration (PC), which is using digital technology to engage in collaboration with other educators, share and exchange knowledge and experiences, and collaboratively innovate in pedagogical practice. Observing the results of tabulated 
data that have been calculated using the Likert scale and presented in the table and figure 4.2 , shows that in the PC-1 item, namely the competence of teachers in using digital technology to collaborate with peers in organizations, for example working on joint projects or exchanging content, knowledge, and opinions in teaching practice are categorized as very good with the achievement of results 4.5. In item PC-2, namely the competence of teachers in using digital technology to explore the latest learning methods with the aim of obtaining inspiring and innovative ideas that are categorized as good with the achievement of results of 4.4. In item PC-3, namely the competence of teachers in using digital technology to share the learning resources that I use, namely knowledge and opinions, collaborate with peers in making learning innovations in the good category with the achievement of results of 4.4. With peers intensively in organizations that are categorized as good with the achievement of results of 4.3. In item PC-4, namely the competence of teachers in using digital technology to collaborate with peers in the learning process is categorized as good with the achievement of results of 4.4. In item PC-5, namely the competence of teachers in using digital technology to collaborating with peers in carrying out learning innovations that are categorized as good with the achievement of results of 4.4 .

Referring to the data analysis of the five items above, based on the category of achievement of results shown through the Likert scale interpretation, the teacher competency profile in the digital learning era and 21 st century skills in the accumulative Professional Collaboration (PC) sub-aspect has been achieved in a good category (with achievements the average result is 4.4) or has been able to meet the criteria for the teacher competency profile as expected. The results of diagrams from the sub-aspects of Professional Collaboration (PC) can be shown as follows:

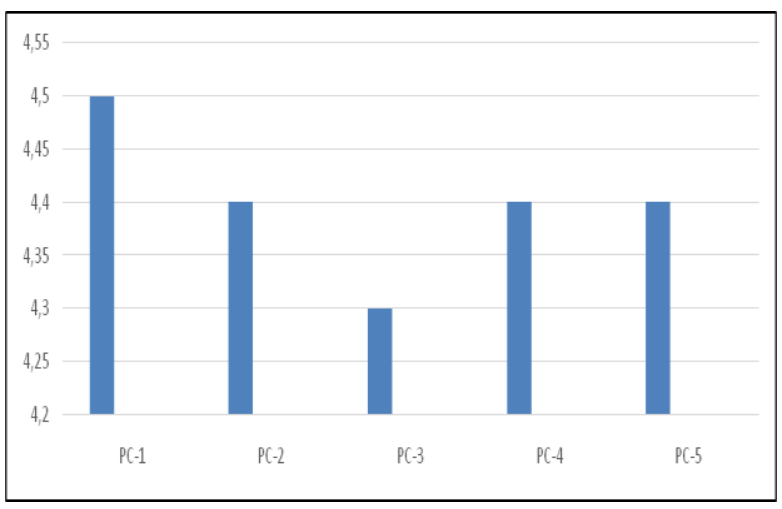


Figure 4.2

Data Tabulation Diagram for the

Aspects of Professional

Collaboration (PC)

The next analysis is the subaspects of Digital Continuous

Professional Development (DCPD), namely the competence of teachers in using digital technology for continuous professional development. Observing the results of tabulated data that have been calculated using the Likert scale and presented in the table and figure 4.3 , shows that in the DCPD-1 item, namely the competence of teachers in using internet facilities to deepen knowledge on subjects that are categorized very well with 4.7 results. In the DCPD-2 item, namely the competence of teachers in using internet facilities for professional development, for example participating in webinars related to training in making instructional video tutorials or similar activities is categorized as good with the achievement of results of 4.3. In the DCPD-3 item, namely the competence of teachers in actively participating in every opportunity to take part in online training or teacher professional development activities by contributing as participants or speakers to improve categorized competencies with the achievementof results of 3,9. In the DCPD-4 item, namely the competence of teachers in actively participating in guiding other participants who take online training or teacher professional development activities in order to be able to make the right choices regarding the use of digital technology for learning in good categories with 3.5 results. Referring to the data analysis of the four items above, based on the category of achievement of results shown through the Likert scale interpretation, the competency profile of teachers in the digital learning era and 21 st century skills in the subaspect of Digital Continuous Professional Development (DCPD) has been achieved in a good category (with achievements the average result is 4.1) or has been able to meet the criteria for the teacher competency profile as expected. Even so, there needs to be furtherefforts to improve teacher competence related to DCPD3 and DCPD-4 items through professional development or similar teacher training. The results of 
diagrams from the sub-aspects of Digital Continuous Professional Development (DCPD) can be shown as follows:

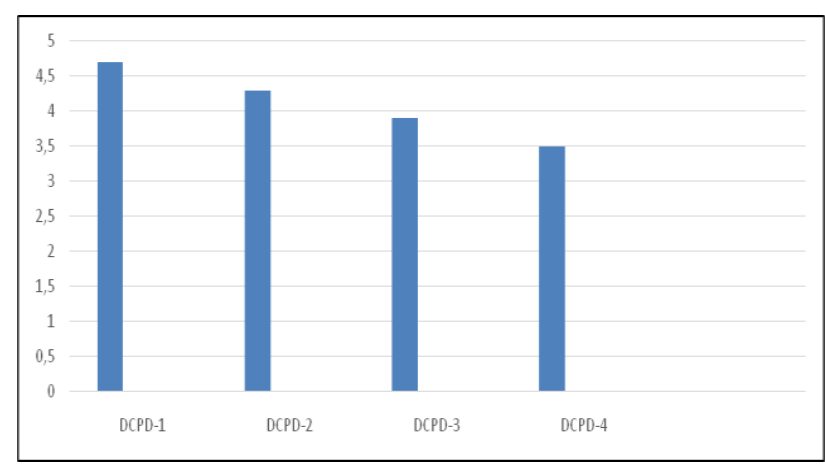

Figure 4.3

Data Tabulation Diagram for Digital Continuous Professional Development (DCPD) Aspects

\section{Selecting Digital Resources}

Selecting Digital Resources (SDR) or identifying, assessing and selecting digital teaching materials to support and improve teaching and learning that can be analyzed through three supporting sub-aspects, namely identifying, assessing, and sorting digital teaching materials itself, designing and modifying digital teaching materials in the learning process (creating and modifying digital resources), as well as organizing digital content and making it available to students, parents and other educators (sharing digital resources).

Observing the results of tabulated data that have been calculated using a Likert scale and are presented in table and figure 4.4 relating to the sub-aspects of Selecting Digital Resources (SDR), it shows that in SDR-1 items, namely the competence of teachers in identifying various appropriate digital teaching materials to support teaching and learning in the subject that is able to be categorized well with the achievement of results of 4.3. In SDR-2 items, namely the competence of teachers to sort various digital teaching materials that are appropriate to support teaching and learning in subjects that are able to be categorized as good with the achievement of results of 4.3. In SDR-3 items, namely the competence of teachers in evaluating the quality of digital teaching materials based on criteria such as places of publication, authors, and feedback from other users are categorized as good with the achievement of results of 4.1. In SDR-4 items, namely the competence of teachers in choosing digital teaching materials that can attract students' learning interest, for example through video shows that are 
categorized as very good with 4.5 results. In SDR-5 items, namely the competence of teachers in using digital teaching materials in the classroom and contextualizing them according to the conditions of students who are categorized as good with the achievement of results of 4.4. In SDR-6 items, namely the competence of teachers in determining access to digital teaching materials that are in accordance with the needs of students is categorized as good with the achievement of results of 4.4. In the SDR-7 item, namely the competence of teachers in determining access to digital teaching materials that are in accordance with the needs of students is categorized as good with the achievement of results of 4.2 .

Referring to the data analysis of the seven items above, based on the category of achievement of results shown through the Likert scale interpretation, the teacher competency profile in the digital learning era and 21 st century skills in the accumulative Selecting Digital Resources (SDR) sub-aspect has been achieved in a good category (with average results of 4.3) or have been able to meet the criteria for the teacher competency profile as expected. The results of diagrams from the Selecting Digital Resources (SDR) sub-aspect can be shown as follows:

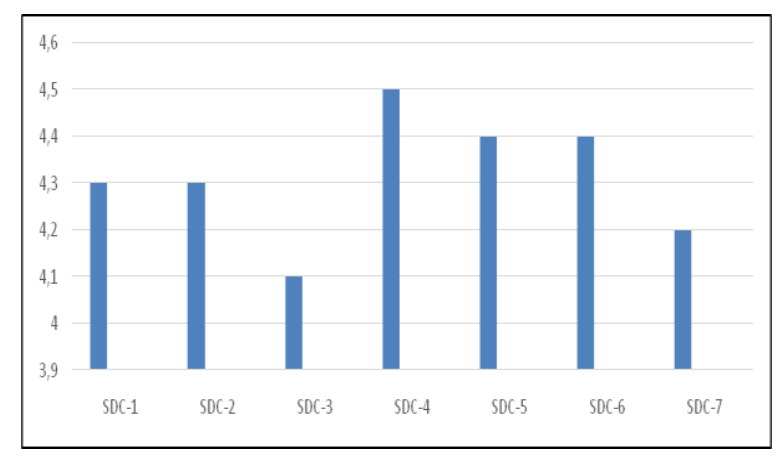

Figure 4.4

Diagrams of Data Tabulation

Results for Selecting Digital

Resources (SDR) Sub-Aspects

Subsequent analysis was carried out on the Creating and Modifying Digital Resources (CMDR) sub aspect or designing and modifying digital teaching materials in the learning process. Observing the results of tabulated data that have been calculated using the Likert scale and presented in the figure 4.5 relating to these sub-aspects, it shows that in the CMDR-1 item, the teacher's competence in determining specific learning objectives when designing digital teaching materials is categorized as good with results 4.2. In the CMDR-2 item, namely the competence of teachers in designing 
digital teaching materials, integrating them with several animations or interactive multimedia access links that are categorized good with the achievement of results of 4.0. In the CMDR-3 item, namely the competence of teachers in modifying interactive and complex digital learning activities, including interactive worksheets, online assessments, collaborative online learning activities, games, applications, and visualization are all categorized as good with a result of 4.3.

Referring to the data analysis of the three items above, based on the category of achievement of results shown through the Likert scale interpretation, the teacher competency profile in the digital learning era and 21st century skills in the accumulative

Creating and Modifying Digital Resources (CMDR) sub-aspect has been achieved in a good category (With an average result of 4.0) or have been able to meet the criteria for the teacher competency profile as expected. The tabulation results of diagrams from the Creating and Modifying Digital Resources
(CMDR) sub aspect can be shown as follows:

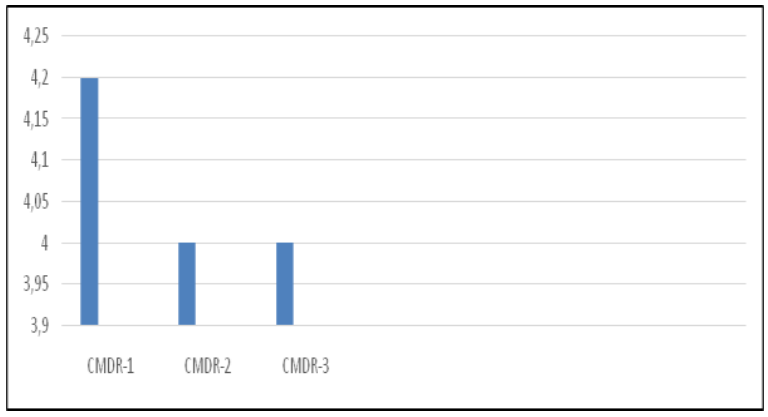

Figure 4.5

Data Tabulation Result Diagram

Sub Aspect Creating and Modifying Digital Resources (CMDR)

Subsequent analysis was carried out on the sub-aspect of Sharing Digital Resources (SDR) or managing digital content and making it available to students, parents and other educators. Observing the results of tabulated data that have been calculated using the Likert scale and presented in the table and figure 4.6 in relation to these sub-aspects, it shows that the SDR-1 item, namely the competence of teachers in storing digital teaching materials for later use independently, is categorized as good with results 4.4. The SDR-2 item, namely the competence of teachers in compiling digital content comprehensively for students or other peers (educators) is categorized as good with the achievement of 
results of 4.2.

Referring to the data analysis of the two items above, based on the category of achievement of results shown through the Likert scale interpretation, the teacher competency profile in the digital learning era and 21 st century skills in the accumulative Sharing Digital Resources (SDR) sub-aspect has been achieved in a good category (with average results of 4.3) or have been able to meet the criteria for the teacher competency profile as expected. The results of diagrams from the Sharing Digital Resources (SDR) sub-aspect can be shown as follows:

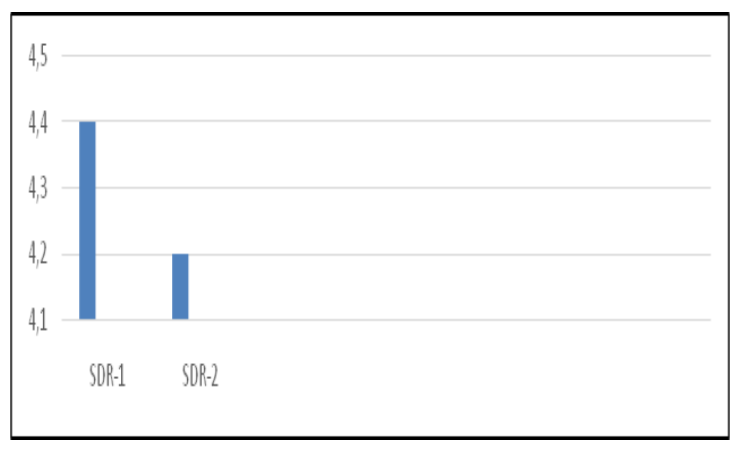

Figure 4.6

Diagram of Data Tabulation Results for Sharing Digital Resources (SDR)

Sub Aspects

\section{CONCLUSION}

Referring to the analysis of respondent data using the Likert scale category interpretation, it is concluded that the two aspects of the accumulative competency profile of teachers in the digital learning era have been achieved in a good category, so that they are able to meet the criteria for the teacher competency profile as expected. The average results in the Likert scale category from every aspect, namely professional engagement (4.3) and selecting digital resources (4.2). Following up on the findings as the conclusion of this study, it is necessary to immediately follow- up efforts in order to improve teacher competencies through professional development or similar teacher training.

\section{REFERENCE}

Ally, M. (2019). Competency Profile of the Digital and Online Teacher in Future Education.

International Review of Research in Open and Distributed Learning , 20 (2), 303-318.

Anna Gruszczynska, Guy Merchant and Richard Pountney. (2013). Digital Futures in Teacher Education": Exploring Open Approaches. Electronic Journal of e-Learning , 193-206.

José Janssen, et al. (2013). Experts' 
views on digital competence: Commonalities and differences.Compedu .

Karmijn van de Oudeweetering, Joke Voogt. (2018). Teachers' conceptualization and enactment of twenty-first century competences: exploring dimensions for new curricula. The Curriculum Journal , 29 (1), 116-133.

Krumsvik, R. J. (2014). Teacher educators' digital competence. Scandinavian Journal of Educational Research, 58 (3), 269-280.

Schmidt, C. (2017). M. D. Anderson Breaks With IBM Watson, Raising Questions About Artificial Intelligence in Oncology. JNCI J Natl Cancer Inst.

Teresa S. Foulger, Kevin J. Graziano, Denise A. Schmidt-Crawford. (2017). Teacher Educator Technology Competencies. Jl. of Technology and Teacher Education , 413-448.

Vickel Narayan, Jan Herrington, Thom Cochrane. (2019). Design principles for heutagogical learning: Implementing studentdetermined learning with mobile and social media tools.
Australasian Journal of Educational Technology , 35 (3), 86-101. 